DOI: http://dx.doi.org/10.22201/iie.18703062e.2000.77.1939

\author{
ROLANDO CARRASCO M. \\ UNIVERSIDAD DE CHILE
}

\title{
El exemplum como estrategia persuasiva en la Rhetorica christiana (1579)
de fray D iego Valadés*
}

Introducción

$\mathrm{R}$

ESU LTA YA UN LUGAR común que el término "retórica" tenga en la actualidad una connotación peyorativa. Su empleo vulgar como designación de un discurso carente de contenido o ajustado a un conjunto de principios y reglas formales difícilmente nos permitiría comprender la trascendencia histórica del Ilamado "arte del bien hablar" en la tradición grecolatina y, más aún, en la cultura hispanoamericana colonial.

D efinida originalmente como la "facultad de considerar en cada caso lo que cabe para persuadir", ${ }^{\text {I }}$ el perfeccionamiento de la oratoria clásica tendría

* Conferencia dictada en el I bero-Amerikanisches Institut de Berlín el 9 de abril de 200 I con el co-referato del doctor G erhard Poppenberg (U niversität Erfurt). La presente actividad se desarrolló en el marco de una beca otorgada por el Servicio Alemán de Intercambio Académico (DAAD). Q uisiera expresar mis agradecimientos al doctor D ietrich Briesemeister por su constante apoyo y colaboración en el desarrollo de mis investigaciones y al doctor Friedhelm Schmidt-W elle por su invitación a dictar esta conferencia. Asimismo, agradezco a las doctoras H elga von Kügelgen y Carmen Loza, y a Settimio Presutto y Elizabeth M änzel por sus sugerencias críticas para este ensayo.

I. Aristóteles, Retórica, traducción, prólogo y notas de Antonio T ovar, M adrid, Instituto de Estudios Políticos, I953, p. Io. Para una visión general de la protorretórica griega, véase James 
DOI: http://dx.doi.org/10.22201/iie.18703062e.2000.77.1939

ROLANDO CARRASCO M.

en la Retórica de Aristóteles uno de sus primeros alcances teóricos. Se dio inicio, de esta forma, a una prolífica reflexión, cuya continuidad en los tratados Del orador y De la invención de Cicerón plantearía nuevas reformulaciones, especialmente por su valor político en la práctica del rhetor. Una ratio dicendi o "arte del pensar" definiría el talento oratorio como una parte de la ciencia del gobierno, cuya finalidad es la persuasión por medio de la palabra. ${ }^{2}$ Este ideal ciceroniano encontraría acogida en la Rhetorica ad herennium del seudo Cicerón y, especialmente, en las Instituciones oratorias de M arco Fabio Q uintiliano. Esta obra señala una nueva etapa en el itinerario, al interrelacionar la retórica con el campo de la preparación moral y educativa del individuo. ${ }^{3}$

La teoría retórica no estuvo al margen de los posteriores cambios histórico-culturales que determinaron su decadencia. La ciencia del rhetor se verá reducida a una expresión panegírica, cultivada en la instrucción escolar, con un fuerte predominio de la palabra escrita. La evolución observada en este campo de la retórica clásica permite advertir, por lo menos, tres aspectos de interés para el humanismo retórico del siglo xvı español. Por un lado, su dimensión metalingüística, mediante reglas y principios que constituyen un sistema preceptivo para la elaboración discursiva; por otro lado, una función política en la llamada "ciencia del gobierno", tal como advirtiera Cicerón, especialmente en relación con el género forense o judicial; y, finalmente, como representación del ideal educativo y moral del individuo de la polis. Desde esta perspectiva, el reestablecimiento del pensamiento grecolatino y la reformulación del trivium medieval influyeron en la reflexión humanista, especialmente referida a la teoría gramatical y retórica. ${ }^{4}$

Tal como ha observado Arturo Andrés Roig, los alcances antropológicos de la teorización lingüística en el humanismo español no sólo marcan un

M urphy, "O rígenes y primer desarrollo de la retórica", en James M urphy, Sinopsis histórica de la retórica clásica, M adrid, G redos, 1989, pp. 20 y SS.

2. C fr. Cicerón, D e la invención, traducción de N icolás Estévanez, París, Garnier H nos., S. f., t. I, p. 207.

3. M arco Fabio Q uintiliano, Instituciones oratorias, M adrid, Librería de la Viuda de Hernando y Cía., I887, 2 vols.

4. Para una visión general sobre el desarrollo de la retórica en España, véase el trabajo de Luisa López G rigera, "Corrientes y generaciones en la retórica del siglo XVı en España”, en La retórica en la España de Siglo de O ro. Teoría y práctica, Salamanca, U niversidad de Salamanca, I994, pp. 49-60. 
DOI: http://dx.doi.org/10.22201/iie.18703062e.2000.77.1939

cambio en la organización interna de las clásicas "artes liberales", sino también una particular función, como medio de expansión del imperio.5 Dicho aspecto plantea una interrogante de fondo sobre el carácter y función de la retórica durante el siglo XVI español, ámbito que ya ha sido analizado en estudios biobibliográficos que han permitido reconstruir la preceptiva oratoria del Siglo de 0 ro. ${ }^{6}$

Los estudios realizados en torno a la teoría peninsular nos llevan a considerar en el marco del presente trabajo la existencia de sistematizaciones preceptivas europeas - tanto en latín como en lengua vulgar- , que circularon en las colonias, o bien de obras que estuvieron en directa relación con un contexto de producción americano. Aún se precisa de un prolijo trabajo de archivo y de ensayos monográficos sobre el fenómeno de recepción de los modelos oratorios en la cultura hispanoamericana colonial de los siglos XVI y XVII. ${ }^{7}$

Cabe destacar en el contexto novohispano una obra como la Rhetorica christiana ( 1579 ) de fray Diego Valadés, fuente que, sin duda, plantea una compleja reflexión en torno a la "oratoria sagrada" y su influencia en el proceso americano de aculturación espiritual. Tanto la figura de este letrado mestizo como su obra han sido objeto de las más diversas aproximaciones teóricas, lo que permite advertir en los últimos años la constitución de una tradición crítica, dispersa en un sinnúmero de libros y artículos. Tal aspecto precisa de una perentoria actualización. En la primera parte de nuestro trabajo se advertirán los principales ejes de lectura desarrollados hasta la fecha. Especialmente en relación con tres ámbitos: la investigación iconográfica, filológico-compara-

5. Cfr. "M omentos y corrientes del pensamiento humanista durante la época de la colonia hispanoamericana: Renacimiento, Barroco ellustración", en Revista deFilosofía, Santiago, diciembre de 1993 , vols. XXI-XXII, p. 59. En el campo de la teoría gramatical cabe hacer presente de qué modo el Ilamado "presagio nebrisense" contenido en su Gramática castellana de 1492 inaugura las expectativas expansionistas de la Corona: "La lengua es siempre compañera del Imperio". C fr. I gnacio G uzmán Betancourt, "La lengua, ¿compañera del imperio? D estino de un 'presagio' nebrisense en la N ueva España", en Cuadernos Americanos, M éxico, enero-febrero de 1993, año vII, vol. I, núm. 37, pp. I48-164.

6. H ago referencia a los estudios de J osé Rico Verdú, La retórica española de los siglos XVI y XVII, M adrid, Consejo Superior de Investigaciones Científicas, 1973; Antonio M artí, La pre ceptiva retórica española en el Siglo de 0 ro, M adrid, Gredos, I972; Karl Kohut, Las teorías literarias en España y Portugal durante los siglos XVI y XVII, M adrid, Consejo Superior de Investigaciones Científicas, 1973; y Luisa López Grigera, op. cit.

7. Cfr. Ignacio O sorio Romero, "La retórica en N ueva España", en Dispositio. Revista H is pánica de Semiótica Literaria, vol. vIII, núms. 22-23, M ichigan, 1983, pp. 65-86. 
DOI: http://dx.doi.org/10.22201/iie.18703062e.2000.77.1939

36

ROLANDO CARRASCO M.

tística y retórico-literaria. En ningún caso corresponden a esferas autónomas; por el contrario, se trataría de prácticas interpretativas que apuntan a subrayar la complejidad estructural y pragmática de una obra que requiere de una revisión crítica, capaz de trascender los esfuerzos meramente reiterativos, como ha sido en muchos casos. A partir de estos antecedentes, en una segunda etapa, estableceremos los deslindes de una nueva aproximación teórica, considerando el tratamiento del exemplum como estrategia persuasiva en la Rhe torica christiana.

\section{La Rhetorica christiana y la tradición crítica}

Fray D iego Valadés nació en T laxcala en I533. D e probable origen mestizo, se sostiene que su madre fue una india tlaxcalteca y su padre el conquistador Diego Valadés, quien combate primero en la expedición de Pánfilo de $\mathrm{N}$ arváez, para luego incorporarse a las tropas de H ernán C ortés y participar en el sitio y toma de Tenochtitlan en el año is2I. D e los pocos antecedentes que se conservan sobre el fraile mestizo, sabemos que, pese a su origen novohispano, ingresó a la orden franciscana. Probablemente estuvo bajo la dirección de fray Pedro de Gante, y fue lector en Santa Cruz de T latelolco desde 1553 hasta su ordenación en 1555 . $^{8}$

La Rhetorica christiana, originalmente escrita en latín, fue publicada en Perugia, Italia, en $1579 .{ }^{9}$ Constituida por un total de seis libros que - de acuerdo con la preceptiva clásica - exponen sistemáticamente los principios, fines y recursos de la teoría oratoria, corresponde a una obra que podríamos

8. Para una revisión actualizada sobre estos antecedentes biográficos, véase el trabajo de I saac V ázquez Janeiro, "Fray D iego Valadés. N ueva aproximación a su biografía", en Actas del II Congreso Internacional sobre los Franciscanos en el Nuevo M undo (siglo XVI), M adrid, D eimos, 1987, pp. 843-87i. En relación con el contexto formativo de $V$ aladés en Tlatelolco, véase $M$ iguel $M$ athes, Santa Cruz de T latelolco: la primera biblioteca académica de las Américas, M éxico, Secretaría de Relaciones Exteriores, 1982.

9. Cfr. fray D iego Valadés, Retórica cristiana, introducción de Esteban J. Palomera, traducción de Tarsicio Herrera Zapién et al., M éxico, U niversidad N acional Autónoma de M éxico, Fondo de Cultura Económica, I989. T odas las citas de esta obra se indicarán con número de página al final de las mismas. $M$ is agradecimientos al I bero-Amerikanisches Institut de Berlín por las facilidades brindadas en la consulta y reproducción de la edición latina de I579. Los grabados que integran el presente trabajo corresponden a la edición del IAI (signatura Y $25 \mathrm{I} 8^{\circ}$ ). 
DOI: http://dx.doi.org/10.22201/iie.18703062e.2000.77.1939

caracterizar como uno de los más vivos testimonios de la evangelización franciscana en N ueva España. Esta experiencia queda registrada por el propio fray Diego en la Rhetorica, al referirse a su actividad como misionero entre los indios chichimecas.

Ya en 1945 la tradición crítica aludiría a tres dimensiones en torno a la figura de fray D iego Valadés como el humanista, grabador, misionero y evangelizador, que tuvo el mérito de ser el primer mexicano que imprimió un libro en Europa, dedicado al sumo pontífice Gregorio XIII. La aportación de los grabados, según Francisco de la M aza, habría de ser fundamental para comprender el que por primera vez se diera a la imprenta un libro que trata y retrata América con un sentido de enseñanza, no de propaganda. De esta forma, Valadés señala a Europa el último problema social que surgía, el problema americano, como una integración de la cultura católica, es decir, universal; y en lugar de recurrir a las antiguas fuentes clásicas en demanda de ejemplos, toma sus propias experiencias vividas y sufridas en su patria. ${ }^{\text {Io }} \mathrm{A}$ este aspecto calcográfico sólo recientemente le han dado seguimiento Elena I sabel de Gerlero (1987), M ario Sartor (1992) y Santiago Sebastián (1995). ${ }^{\text {II }}$

En el ámbito filológico, G abriel M éndez Plancarte (I946) sería uno de los primeros en llamar la atención sobre la obra de este "humanista criollo" y el carácter diferenciador que significaba - para un receptor europeo- la inserción en un tratado de retórica de descripciones de los templos indígenas y de los dioses mexicanos, de las danzas y sus fiestas, así como de la defensa del sincero cristianismo de los recién convertidos. ${ }^{12}$ La traducción parcial de la obra valadesiana sería continuada en 1962 por Esteban Palomera, quien publicara uno de los estudios fundamentales sobre este humanista mexicano. En su ensayo no sólo se entregan valiosos antecedentes referidos a la figura

Io. En torno a este aspecto sigo el planteamiento de Francisco de la M aza, "Fray D iego Valadés. Escritor y grabador franciscano del siglo Xvı", en Anales del Instituto de Investigaciones Estéticas, núm. 13, M éxico, 1945, pp. 97-159.

II. Cfr. Elena Isabel E. de G erlero, "La demonología en la obra gráfica de fray D iego Valadés", en I conología y sociedad. Arte colonial hispanoamericano, XLIV Congreso Internacional de Americanistas, M éxico, U niversidad N acional Autónoma de M éxico, 1987, pp. 79-89; M ario Sartor, Ars dicendi et excudendi: D iego Valadés incisore messicano in I talia, Padua, CLEUP, I992; Santiago Sebastián, "EI franciscano V aladés y la capilla abierta”, en I conografía de arte del siglo XVI en M éxico, M éxico, U niversidad Autónoma de Zacatecas, 1995, pp. IOI-IO4.

I2. Gabriel M éndez Plancarte, H umanismo mexicano de siglo XVI, M éxico, U niversidad N acional Autónoma de M éxico, 1946. 
DOI: http://dx.doi.org/10.22201/iie.18703062e.2000.77.1939

ROLANDO CARRASCO M.

del fraile en el contexto de la tradición humanista del siglo Xvı, sino también sobre la influencia de la Retórica eclesiástica (1578) del teólogo español fray Luis de Granada y el aporte de la Rhetorica christiana al proceso de evangelización en N ueva España. ${ }^{13}$

En los últimos 20 años, gracias a los esfuerzos de recopilación y catalogación de los textos utilizados para la enseñanza del latín en las aulas novohispanas, las teorías gramaticales, poéticas y retóricas comienzan a ser analizadas con el objeto de establecer su aporte al proceso de formación del pensamiento crítico-literario colonial. ${ }^{\mathrm{I}}$ En el caso de la Rhetorica christiana, la investigación de René Taylor (1987) ya ha demostrado la originalidad de la concepción mnemotécnica que expone el fraile mestizo, quien adapta los principios de la memoria artificial a las circunstancias existentes en M é xico y, en concreto, a las misiones indígenas. ${ }^{15}$ En esta perspectiva, otro de los trabajos de interés es la obra de D on Paul Abbott (1996), quien dedica un interesante capítulo a Valadés en el contexto de su estudio sobre la influencia de la retórica en las colonias de $\mathrm{N}$ ueva España y Perú. ${ }^{16}$ Especial atención merece a este respecto la influencia de la teoría mnemotécnica en los métodos de alfabetización y enseñanza de la doctrina cristiana a los indígenas. ${ }^{17}$

I3. Esteban J. Palomera, Fray Diego Valadés O. F. M. Evangelizador humanista de la N ueva España, M éxico, Jus, 1962.

I4. Esta línea de investigación que diera a conocer I gnacio 0 sorio Romero sólo tardíamente ha tenido cierta continuidad: Floresta de gramática, poética y retórica en N ueva España (IS2II767), M éxico, U niversidad N acional Autónoma de M éxico, 1980. Tenemos conocimiento de dos trabajos en esta línea: Francisco J avier C eballos, "I mitatio, aemulatio, elocutio. H acia una tipología de las poéticas de la época colonial", en Revista I beroamericana, Pittsburg, julio-diciembre de I995, LXI, I72-173, pp. 50I-5I5; D ietrich Briesemeister, "La estela de N ebrija en el N uevo M undo: la gramática y retóricas latinas", en Karl Kohut y Sonia Rose (editores), Pensamiento europeo y cultura colonial, Frankfurt del M ain, Vervuert-M adrid, Iberoamericana, I997, pp. 52-67.

15. René C. Taylor, El arte de la memoria en el N uevo M undo, M adrid, Swan, 1987. Véase, además, Juan Carlos Gómez Alonso, "Retórica y poética en los siglos XVI y XVII: la operación retórica de memoria", en Edad de O ro, núm. I9, M adrid, 2000, pp. I2I-I30.

I6. D on Paul Abbott, "D iego Valadés. An Ancient Art in a N ew W orld", en Rhetoric in the $\mathrm{N}$ ew W orld. Rhetorical Theory and Practice in Colonial Spanish America, Columbia, South Carolina Press, 1996, pp. 4I-59.

17. C fr. Carmen José Alejos-Grau, Diego Valadés, educador de la Nueva España. Ideas pe dagógicas de la Rhetorica christiana ( I579), Pamplona, Eunate, 1994. 
DOI: http://dx.doi.org/10.22201/iie.18703062e.2000.77.1939

Finalmente, la teorización sobre los discursos que se inscriben en "fronteras culturales" también ha encontrado en la obra de Valadés un modelo privilegiado para la reflexión en torno al proceso de formación discursiva durante el siglo Xvı, especialmente referido al análisis de la llamada "cuestión de la letra" en el Nuevo Mundo. Dicha problemática nos sitúa, por un lado, frente a la necesidad de identificar las teorías elaboradas en Europa sobre la experiencia escritural alfabética y, por otro lado, las teorías construidas en las grandes civilizaciones prehispánicas. ${ }^{18}$

Como podemos observar, la Rhetorica christiana constituye un modelo preceptivo de interés para el análisis de las conceptualizaciones discursivas durante el siglo XVı en N ueva España, sean éstas de naturaleza gramatológica como también orales y pictográficas. Pese a esto, se advierte que parte de esta tradición ha tendido a privilegiar la figura de este franciscano novohispano desde ciertos presupuestos biográficos e ideológicos, acentuando más su condición mestiza y admirativa por el pasado indígena, que estrictamente los contextos retórico-preceptivos y doctrinales que determinaron tanto la producción como recepción de su obra. ${ }^{19}$ En esta perspectiva, podemos inscribir la reciente crítica de Gerardo Ramírez Vidal, en la medida en que "estos pensamientos han sido expresados más por un deseo de encontrar un ancla en nuestro pasado o de mitigar, con la imagen de una figura emblemática, la brutalidad de la conquista, más que a partir de un examen cuidadoso de la Rhetorica christiana". ${ }^{20}$

I8. D e la amplia producción crítica de W alter M ignolo, véanse sus planteamientos sobre Valadés en "Palabras pronunciadas con el corazón caliente: teorías del habla, del discurso y de la escritura", en Ana Pizarro (coordinadora), América Latina. Palavra, literatura e cultura. Formações discursivas coloniais. Vol. I. A situacão colonial, São Paulo, Fundacão M emorial da América Latina Campinas, UN ICAM P, 1993, pp. 527-562.

19. A la fecha no sabemos de la existencia de trabajo alguno que haya considerado el estudio de la recepción de la obra de Valadés en el contexto europeo. C abe señalar que fray Valentino Fricio realizó una traducción parcial al alto alemán de la Rhetorica y de la Crónica de la O rden D escalza de fray Francisco de Gonzaga. Bajo el título de Indianischer Religionstandt der gantzen N euen W elt, beider Indien gegen auff (und) nidergang der Sonnen, esta obra fue dedicada al archiduque de Austria M atías e impresa en Ingolstadt hacia 1588. M is agradecimientos a la doctora $\mathrm{H}$ elga von Kügelgen por facilitarme las microfichas correspondientes al texto alemán.

20. Gerardo Ramírez Vidal, "Fray D iego Valadés y los indios", en Acerca de fray D iego Valadés: su Retórica cristiana (Bulmaro Reyes Coria, Gerardo Ramírez Vidal, Salvador Díaz Cíntora), M éxico, U niversidad N acional Autónoma de M éxico, 1996, pp. 9-33. 
40

ROLANDO CARRASCO M.

En resumen, y pese a los avances críticos mencionados, son escasos en la actualidad los efectivos intentos de relectura en que - sin caer en los espejismos identitarios o repetitivos- se ha logrado superar ciertos clichés de la crítica valadesiana con un verdadero rigor histórico-filológico, lo que permitirá establecer una nueva aproximación textual desde las mismas estructuras retórico-argumentativas. Por esta razón se hace necesario considerar aquella observación que D ietrich Briesemeister enunciara a propósito de esta obra, pues "Io que a primera vista parece ser un acto violento de europeización forzada - la inculcación de modelos de pensar europeos- es en realidad una estratagema argumentativa para revalorizar al indio en su plena facultad racional que plasma el espíritu universalmente válido del humanismo cristiano". ${ }^{21}$ Los alcances de esta reflexión nos deben hacer reconsiderar no sólo la naturaleza preceptiva de esta obra - desde un punto de vista de su composición estructural - , sino también de qué modo estos elementos se integran en una lectura retórica del proceso de evangelización en las Indias, es decir, como un dispositivo persuasivo en que se integran sus distintos niveles retórico-discursivos, sean éstos de orden preceptivo o iconográfico. Estos aspectos muchas veces han sido desarticulados por la crítica, mediante su análisis, como esferas independientes, sin un cuestionamiento acotado sobre su carácter y su función, desde el punto de vista de la "ejemplificación" retórica.

A nuestro juicio, en la complejidad discursiva (preceptiva e iconográfica) de la Rhetorica christiana confluyen diversas tradiciones que se integran en una específica visión del hombre americano y de la historia que, gracias a la utilización retórica del exemplum, pone en discusión ante sus destinatarios europeos no sólo la supuesta inferioridad natural del indígena americano, sino también su integración en la cultura cristiana universal. En las páginas siguientes intentaremos identificar de qué modo, gracias a la introducción de los "ejemplos de indios", se actualizan ciertas estrategias retóricas y concepciones que permiten demostrar la utilización persuasiva de este recurso al interior de su articulación lingüística e iconográfica.

2I. Cfr. Briesemeister, op. cit., p. 6o. Lo destacado es mío. 
DOI: http://dx.doi.org/10.22201/iie.18703062e.2000.77.1939

EL EXEMPLUM COMO ESTRATEGIA PERSUASIVA

La retórica de los exempla como estrategia persuasiva

Rhetorica Christiana ad concionandi et orandi usum accommodata, utriusque facultatis exemplis suo loco insertis, quae quidem, ex indorum maxime deprompta sunt historiis unde praeter doctrinam, summa quoque delectatio comparabitur auctore Rdo. admodum P. F. D idaco Valades totius 0 rdinis Fratrum $M$ inorum regularis observantiae olim procuratore generali in romana curia anno Domini M .D.LXXVIII.

Con esta inscripción en la portada de su Rhetorica christiana (figura I), fray D iego Valadés habría de introducir un elemento de clara originalidad en relación con la oratoria sagrada peninsular del siglo xvı. La utilización de "ejemplos" - correspondientes a las historias de los indios novohispanosactualiza uno de los procedimientos argumentativos tradicionales desde los tiempos de la retórica grecolatina. Para Q uintiliano, su utilización como prueba extrínseca consistía en "traer un hecho sucedido o como sucedió, útil para probar lo que queremos". ${ }^{22}$ En tal sentido, el "ejemplo", gracias a su función de prueba inartística, establece una relación con la tesis mediante la interpretación, más o menos subjetiva, del escritor, y cabe considerarla, según C ristóbal Cuevas, como una "parte de la probatio", y pertenece a "Ios lugares de donde se sacan los argumentos [loci] con que principalmente se trata la cuestión". ${ }^{23}$ Frente a este propósito, ya consagrado por la retórica tradicional, habría que aducir también una función catequética, como ilustración 0 "icono verbal" del sentido de una doctrina, lo que convierte al exemplum en un elemento ampliamente significativo para la oratoria sagrada.

A juicio de Antonio M artí, la retórica sacra - en que se inscribe la obra de Valadés- debe ser considerada en una doble vertiente, pues, en cuanto retórica, seguía las normas de los grandes maestros (Aristóteles, Cicerón y Q uintiliano); en cuanto sacra, tenía que hallar su identidad por medio del elemento sobrenatural que la diferenciaba de la forense. ${ }^{24}$ De esta forma, el

22. Cfr. Quintiliano, op. cit., p. 272.

23. Cristóbal Cuevas, "Para la historia del exemplum en el Barroco español (El Itinerario de Andrade)", en Edad de 0 ro, núm. 8, M adrid, 1989, pp. 59-75. U na fuente importante en relación con este tema es la obra de Félix H errero Salgado, La oratoria sagrada española de los siglos XVI y XVII, M adrid, Fundación U niversitaria Española, I996.

24. Cfr. Antonio Martí, "La retórica sacra en el Siglo de O ro", en H ispanic Review, vol. XXXVIII, núm. 3, Filadelfia, julio de I970, pp. 264-298. 
DOI: http://dx.doi.org/10.22201/iie.18703062e.2000.77.1939

42

ROLANDO CARRASCO M.

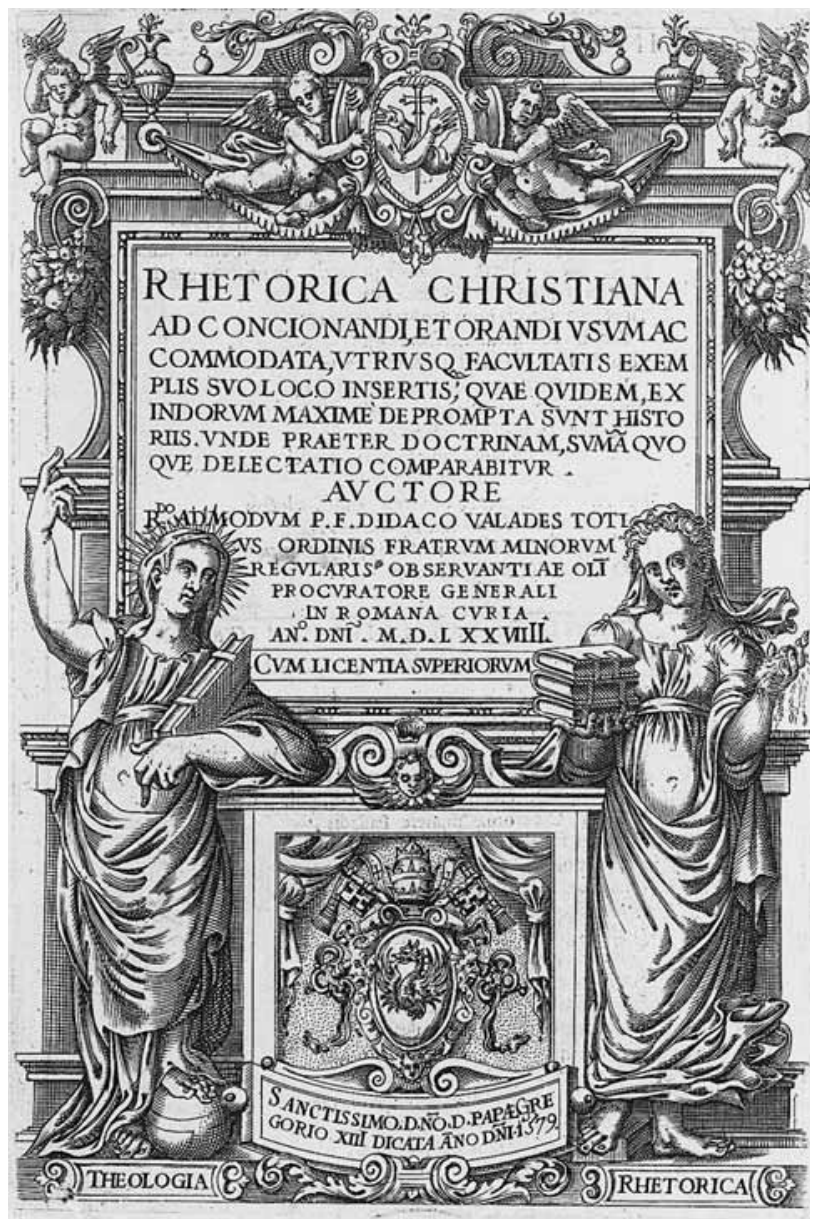

Figura i. Portada de la Rhetorica christiana de fray Diego Valadés, Perugia, is79. Cortesía del Ibero-Amerikanisches Institut Preussischer Kulturbesitz.

ejemplo religioso debía ofrecer ciertos "paradigmas éticos", basados en la conducta de santos o pecadores. Resulta preciso que la temática presente en el exemplum no sólo sea compatible con el contexto teológico y moral, sino también que la situación final de la narración esté en perfecta adecuación con la conducta exigida por el principio moral. En su conjunto, trataríase de 
elementos que a través de la predicación pretenden conmover, convencer al entendimiento y enardecer la voluntad de cambio espiritual en su receptor. ${ }^{25}$

En este contexto, la inscripción de ejemplos pertenecientes a las "historias de los indios" de N ueva España, a modo de hipótesis, nos plantea la posibilidad de abordar este componente de la Rhetorica christiana como un recurso que presentaría una función probatoria; por tanto, responde a una estrategia argumentativa que precisa ser descodificada desde una doble vertiente. Por un lado, como principio demostrativo (elogio) de la acción evangelizadora realizada por los franciscanos en el N uevo M undo; y, por otro, como defensa de esta misión frente a la crítica europea sobre la efectividad de sus métodos y el sincero cristianismo de los indianos, lo que reconceptualiza su original carácter didáctico y moralizador en una controversia de carácter judicial sobre la historia espiritual del N uevo M undo.

\section{La "invención" de una historia espiritual de N ueva España}

En un sentido general, podemos señalar que estas crónicas de la vida prehispánica que componen la Rhetorica, tipológicamente pueden considerarse como un "exemplum histórico" de la evangelización en el Nuevo M undo. Dicho aspecto plantea una determinada perspectiva de enunciación frente al indígena, que está en relación con la conceptualización de su potencial destinatario, los futuros predicadores europeos de la época y el papa Gregorio XIII. Este elemento nos hace suponer que, más allá del carácter didácticopreceptivo de la obra - referido a una aplicación práctica de la oratoria sagrada- , en ella se hacen evidentes los signos de una estrategia de legitimación y defensa del nuevo orden espiritual americano.

Siguiendo los principios del origen de la retórica contenidos en el De inventione de Cicerón, Valadés refiere en los siguientes términos la función del "arte del bien hablar":

También a su tiempo traeremos ejemplos tomados de los sucesos de las Indias, entre cuyos habitantes no sólo vivimos, sino que estuvimos encargados de ellos;

25. Para una discusión teórica sobre la definición y tipología del exemplum, véase el trabajo de $\mathrm{M}$ aría D olores $\mathrm{N}$ ieto, Estructura y función de los relatos medievales, $\mathrm{M}$ adrid, Biblioteca de Filología H ispánica, Consejo Superior de Investigaciones Científicas, I993, cap. I, "La narrativa breve medieval: El exemplum", pp. 3-15. 
DOI: http://dx.doi.org/10.22201/iie.18703062e.2000.77.1939

44

ROLANDO CARRASCO M.

creemos que esto no solamente servirá de solaz sino que será al go provechoso, ya que en ello se apreciarán claramente los principios, el desarrollo y la aplicación práctica de la retórica, como lo atestigua Cicerón cuando dice: "Existió un tiempo en que los hombres, a maneras de bestias, vagaban por la tierra y luchaban por la vida, y se hacían justicia no en virtud de la razón sino de la fuerza. $\mathrm{N}$ inguno conocía las legítimas nupcias, ni sabía con certeza quiénes eran sus hijos. Entonces, un hombre sobresaliente, impulsado por al gún móvil superior, reunió a los hombres dispersos por la llanura y escondidos en los bosques y los convirtió de fieras salvajes en hombres apacibles y mansos." Yo diré que los admirables efectos de esta influencia, en ningún lugar aparecen más claros que en la pacificación de los indios de este $\mathrm{N}$ uevo M undo del mar océano. (27-29)

La significación que Valadés atribuye a la retórica, en primera instancia, se realiza desde una estrategia de legitimación empírica, con el fin de demostrar su introducción en el orbe indiano. Con ello, se apela a la recepción de estos exempla desde una perspectiva que apuntaría a demostrar la efectividad de la tarea aculturadora sobre el Ilamado paganismo. El cultivo de la elocuencia sagrada y la práctica de la conversión "libera" al indígena de una condición comparable a la de animales, que es posible transformar gracias a la razón, el respeto a las leyes y el cambio en las costumbres, elementos indispensables para la vida en comunidad y la instauración de la convivencia familiar como núcleo de un nuevo orden social y espiritual en las Indias.

La fuente valadesiana establecerá asimismo una primera distinción entre el orador y el predicador; este último, a diferencia del conocimiento de los filósofos profanos, debe mover el ánimo de los oyentes a amar a Dios y a detestar los pecados. ${ }^{26}$ Sus efectos en la "pacificación" del N uevo M undo, cier-

26. Bulmaro Reyes Coria analiza este fenómeno de recepción del tratado en la obra de Valadés en su ensayo "El D e inventione de Cicerón en la N ueva España", en Acerca de fray D iego Valadés. Su Retórica cristiana, M éxico, U niversidad N acional Autónoma de M éxico, 1996, pp. 35-52. Para el crítico, el fraile toma la lengua y el método de Cicerón, introduciendo algunas omisiones en la definición dada en el libro I del De inventione; con ello se aparta del pensamiento clásico, minimizando el valor de la filosofía pagana y sustituyendo lo vital de la retórica de Cicerón, el espíritu combativo de los romanos, por otro de humildad y sumisión. Si bien podríamos considerar válidas las observaciones de Reyes C oria, creo que éste olvida que ya en Brunetto Latini (I2I2-I294) la recepción del pensamiento ciceroniano permite reconocer las omisiones anteriormente advertidas, con énfasis en la capacidad única y originaria que adquiere la elocuencia en la fundación de la comunidad y en la identificación de los valores del orador cristiano. 
DOI: http://dx.doi.org/10.22201/iie.18703062e.2000.77.1939

tamente, representan la base del encomio valadesiano, referido al valor de la elocuencia en la fundación de la comunidad cristiana, pero también el marco de una descriptio de la cultura y tradiciones de los indianos. Para esto Valadés recurre en su libro IV al análisis de los distintos géneros oratorios (demostrativo, deliberativo y judicial), materia que ofrecía un lugar privilegiado para la difusión y discusión sobre la cultura prehispánica en relación con tres núcleos temáticos: Los indios en su gentilidad (capítulos I-IV), La predicación de las verdades del Evangelio a los indios y su sincera conversión a la fe católica (capítulos V-XI) y La llegada de los primeros misioneros. Cristiana y radical transformación operada en las costumbres de los indios (capítulos XII-XVI). ${ }^{27}$ En las páginas siguientes abordaremos críticamente al gunos aspectos de estas unidades textuales, con el objeto de esclarecer sus estrategias retórico-discursivas en relación con la visión del mundo americano.

El N uevo M undo en la historia cristiana universal

La clasificación de los géneros oratorios ya estaba preestablecida por las fuentes de la tradición clásica. Así, por ejemplo, a la finalidad persuasiva o disuasiva del género deliberativo se suma la acusación y defensa del género judicial y, por último, el elogio o el vituperio del género demostrativo o epidíctico. Especialmente, hemos de considerar el val or de este último género, cuando Valadés señala: "me he determinado a insertar en este lugar una narración de las costumbres (de los indios)". ${ }^{28}$ Como hemos señalado, su tratado incorpora un uso específico del Ilamado "ejemplo histórico", en la medida en que confluye la fuerza testimonial de su experiencia en la conversión de los infieles Ilamados chichimecas, de los que - según confiesa en el prólogo al Itinerarium catholicum - a duras penas pudo escapar. ${ }^{29}$

En el ámbito de la historiografía indiana, la "construcción" de la verdad que define este tipo de textos recurre a ciertas estrategias persuasivas que ase-

27. En esta segmentación acogemos la distribución propuesta por Esteban Palomera (1962), quien dedica la tercera parte de su obra al análisis de la "Crónica mexicana de Valadés", pp. 209-3I2.

28. Valadés, op. cit., p. 387.

29. Cfr. Juan Focher, Itinerarium catholicum (texto latino con versión castellana, introducción y notas de Antonio Eguiluz), M adrid, Librería G eneral Victoriano Suárez, I96o, pp. 9-ıo. 
DOI: http://dx.doi.org/10.22201/iie.18703062e.2000.77.1939

46 ROLANDO CARRASCO M.

guran su credibilidad ante el destinatario europeo..$^{\circ \circ}$ En Valadés, la búsqueda de estos recursos se asienta en su propia experiencia misionera entre los indígenas, con lo cual recobra la identificación entre el ver y el saber, pues, como señala: "he morado entre ellos treinta años más o menos, y me dediqué durante más de veintidós a predicarles y confesarlos en sus tres idiomas: mexicano, tarasco, otomí". ${ }^{\text {I }}$ En este sentido, la exposición de sus tradiciones, ritos y costumbres se realiza desde una experiencia evangelizadora, que persigue, en última instancia, demostrar que "abunda en muchos errores y mentiras la historia de la N ueva España y de todo el N uevo M undo". ${ }^{32} \mathrm{Di}$ cho aspecto determinaría su perspectiva de enunciación, mediante la elaboración de un modelo retórico-teológico que pretende demostrar la continuidad humana de una historia cristiana universal en las Indias. Previamente a esto, se hacía necesaria la integración de estas noticias en la Rhetorica christiana, con el objeto de entregar una primera impresión de diversos aspectos de la vida y costumbres indígenas:

a. La estructura y disposición de los templos indígenas (capítulo Iv):

Los templos están frecuentemente colocados en montículos hechos por ellos mismos y tienen una forma semejante a las pirámides de Egipto. Los españoles llaman a esos templos "Cúes". Estaban rodeados de muros muy elegantes y cerrados por medio de canceles y celosías. Se llega a ellos por medio de artificiosas escalinatas adornadas de muy diversas maneras [... ] Embellecían esos templos, jardines, amenas fuentes, baños termales, al bercas y verdes huertos deliciosos por sus flores y sus árboles, pues tienen flores de exquisita y variada fragancia. Plantaban en esos huertos, con grande cuidado, árboles muy anchos y frondosos; tanto así, que bajo la sombra de uno de esos árboles se podían estar mil hombres sentados, a la manera que acostumbran los indios. Y aunque este árbol es estéril y no

30. C fr. W alter M ignolo, "El metatexto historiográfico y la historiografía indiana", en M odern Language $\mathrm{N}$ otes, vol. 96, núm. 2, Baltimore, 198I, pp. 358-402.

3I. Valadés, op. cit., p. 425.

32. Según Salvador D íaz C íntora, en la traducción al español de la obra de Valadés se habría omitido en este pasaje la referencia del fraile a la escritura de una historia que amenaza con escribir o que ya estaba escrita, y en la que se enmendarían estos errores de su época. Si bien nos parece una hipótesis plausible, este aspecto no aminora el sentido de crítica que puede observarse en algunos pasajes de la obra, especialmente referidos a la problemática de los métodos misionales y las disputas entre el clero regular y secular. Cfr. "Fray D iego Valadés: un autor difícil, una traducción desigual", en Bulmaro Reyes Coria, op. cit., pp. 53-I29. 
DOI: http://dx.doi.org/10.22201/iie.18703062e.2000.77.1939

EL EXEMPLUM COMO ESTRATEGIA PERSUASIVA

Ileva fruto ninguno, es sin embargo tan estimado que frecuentemente se toma como punto de partida para apreciar los árboles de mayor valor. Los indios le llaman "Ahuéhuetl" y los españoles "Árbol del Paraíso"; pero a mí me parece que el ahuéhuetl y el árbol del paraíso no son de una misma especie. Todo el año están verdes, son muy semejantes al plátano, y sin embargo no son completamente de la misma naturaleza, como lo explicaremos en el catálogo de las variadas cosas procedentes del N uevo M undo. (389)

b. Los sacrificios a los dioses mexicanos (capítulo VII):

Yo mismo supe, de boca de ciertos indios ancianos, que en el templo de Tetzcutzingo, que dista media milla de T excoco, se habían inmolado años atrás en un solemne sacrificio, setenta y seis mil hombres, hechos prisioneros en la guerra contra los $T$ laxcaltecas (espectáculo que ciertamente es digno de lamentarse y deplorarse); el cual templo era el más famoso de todos, cuyas ruinas aún pueden verse en el presente. $M$ as esta ferocidad, propia de animales, ha sido ya trocada en mejor condición por la bondad divina, gracias a Fray M artín de V alencia y a once padres que le acompañan, los cuales, como doce lumbreras, a semejanza de los doce apóstoles, fueron los primeros de nuestra orden franciscana que marcharon a ese $\mathrm{N}$ uevo $\mathrm{M}$ undo para establecer la nueva I glesia [... ] Pues convirtieron y todavía convierten, como después expondremos, una muchedumbre innumerable, desarraigando el culto del demonio y los homicidios y sacrificio, tan horrendos como nunca han sido vistos y oídos ejemplos parecidos en ninguna otra nación, que se llevaba a efecto entre estos bárbaros. (395)

Al momento de considerar la perspectiva de enunciación narrativa, podemos establecer que la posición del sujeto que construye los acontecimientos y caracteres del relato nos ofrece un punto de vista narrativo individual, consolidado y coherente con una finalidad persuasiva, la legitimación del proyecto evangelizador novohispano. Pese a la descripción encomiástica de sus templos y la asimilación de esta realidad americana mediante su comparación con el orden europeo (pirámides, árboles), la utilización de estrategias de veridicción como "yo mismo supe", y la fijación de su posición valórica en relación con este tipo de prácticas rituales, consideradas "lamentables" y "deplorables", dan como resultado la constitución de una perspectiva que legitima la conquista espiritual. Con ello Valadés apela a una larga tradición teológica y retórica que tiene como centro explicativo al demonio, principal 
DOI: http://dx.doi.org/10.22201/iie.18703062e.2000.77.1939

48

ROLANDO CARRASCO M.

causa del idolatrismo indiano y del proyecto de extirpación que se desarrolló en las Indias. 33

Por otro lado, la introducción de los indios a la espiritualidad cristiana, gracias a la acción de los llamados "doce apóstoles", no sólo pretende arrancar las creencias y prácticas prehispánicas del paganismo, sino también introducir una determinada visión de la historia. En tal perspectiva, en la teoría misional americana, la descripción de los cultos prehispánicos como demoniacos se basaba en una tradición bíblica cuyos alcances no era posible poner en duda:

Sin embargo, al hacer este juicio negativo sobre el culto indígena, los misioneros lograron poner de manifiesto que los indios pertenecían plenamente a la humanidad, dado que la característica más acusada del demonio es ser enemigo del gé nero humano. D e ello pudo concluirse que si los indios no fueran hombres o no lo fueran de modo pleno, el demonio ningún interés tendría en ellos [... ]. Si Satanás llevó a los pueblos prehispánicos a la idolatría, como antes llevó al mundo greco-latino a este mismo y aborrecible pecado, es porque tan hombres son unos como otros. ${ }^{34}$

A mi modo de entender, dicho principio conlleva una estrategia retórica que pretende legitimar la incorporación del indígena en una unidad de la naturaleza humana. Previamente a esto se hacía necesaria la afirmación de la "otredad" novohispana y el cambio hacia una identidad espiritual; en otros términos, el ingreso de estas culturas en una concepción de la historia cristiana, entendida como una "historia de la salvación", cuyas claves simbólicas no sólo se identifican en el nivel retórico-preceptivo, sino también iconográfico. D esde esta perspectiva, el grabado referido al Templo y las costumbres indíge nas (figura 2) dispone la ubicación central del teocali en forma piramidal, y la consciente alteración de una suerte de capilla, en que se representa la idolatría indígena y un sacrificio ofrecido a una romanizada figura del dios H uitzilopochtli. Tales elementos se integran en un conjunto de escenas de la vida

33. En relación con los al cances de esta idea en el contexto andino, véase el estudio preliminar de H enrique U rbano, La extirpación de la idolatría en el Pirú (I62I). Pablo J oseph de Arriagada de la Compañía de Jesús, C uzco, CBC, I999, pp. xxxI SS.

34. Elsa Cecilia Frost, "La visión providencialista de la historia", en Filosofía iberoamericana en la época del Encuentro, M adrid, Trotta, 1992, pp. 33I-345. 


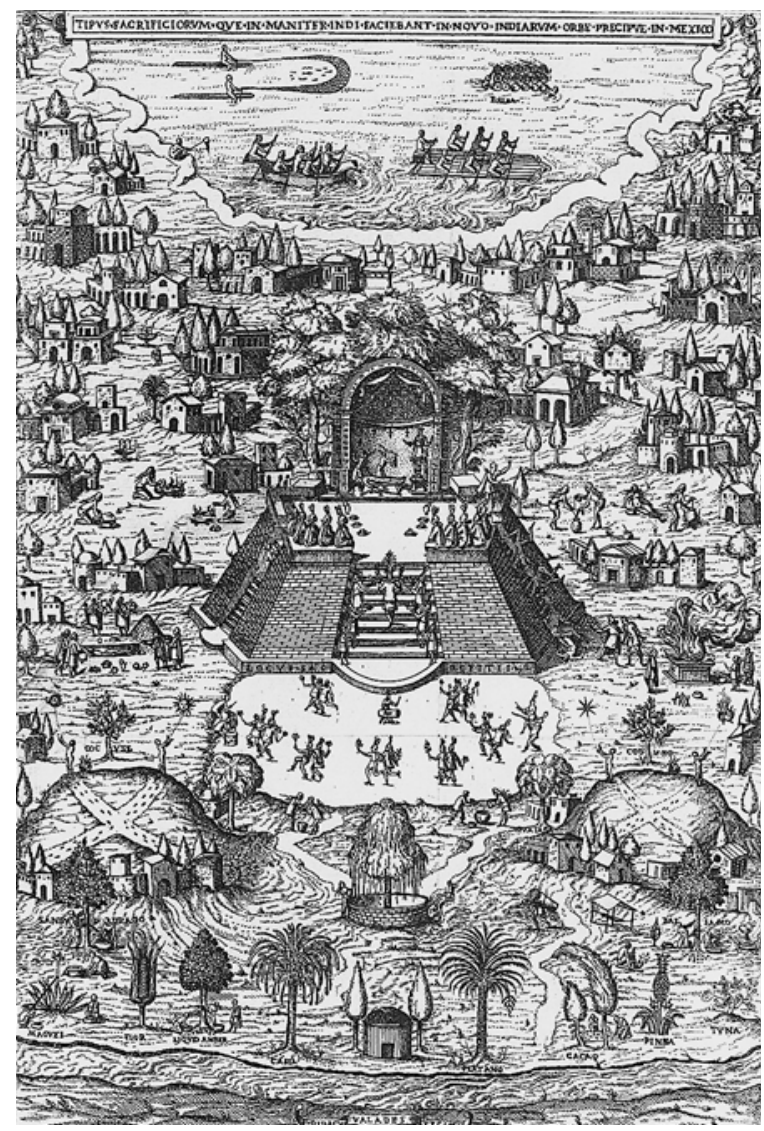

Figura 2. Templo y costumbres indígenas, en fray Diego Valadés, Rhetorica christiana, Perugia, I579.

indígena: la pesca, la succión del pulque, la sangría del árbol del dragón, los sacerdotes astrólogos en las colinas y la inscripción de la flora americana. En definitiva, un claro esfuerzo por entregar una determinada visión de la cultura indígena, lo que para la historiografía americana no sólo era un dilema antropológico, sino también jurídico-eclesiástico y epistemológico.35 Los mar-

35. H acia isso la polémica entre juristas y religiosos, como fray Bartolomé de las Casas y Juan Ginés de Sepúlveda, señala uno de los puntos más álgidos del enfrentamiento de dos corrientes en pugna: la tradición griega de bases aristotélicas y la cristiana. C fr. Beatriz Fer- 
DOI: http://dx.doi.org/10.22201/iie.18703062e.2000.77.1939

50

ROLANDO CARRASCO M.

cos comparativos que orientan visualmente la representación de Valadés sobre el indígena cristianizado hunden sus raíces en el humanismo cristiano social del renacimiento, razón por la cual la eliminación de las prácticas idolátricas del mundo prehispánico respondería, en el mejor de los casos, al resultado de un proyecto educativo que construye esta nueva al teridad novohispana desde las bases de una conciencia alfabética-letrada y de una interpretación providencialista de la historia. ${ }^{36}$

\section{La gran cadena del Ser}

En la Rhetorica christiana la afirmación de la unidad espiritual de la naturaleza humana constituye una fuerza argumentativa de importancia, que adquiere una nueva significación en la medida que propicia la integración de las culturas prehispánicas en un modelo cristológico de la Creación del mundo. Es interesante destacar de qué modo la sucesión jerárquica de especies, identificable en su grabado alusivo a la Alegoría de la Creación (figura 3), completa una taxonomía en que el componente americano no está excluido de esta gran cadena del Ser. ${ }^{37}$ Aquí Valadés ubica en la parte superior la Trinidad y los ángel es que rodean la majestad de D ios, quien lleva en su diestra una cadena que, como símbolo de unión, establece un principio de sujeción a un orden espiritual que gobierna toda la C reación que se desarrolla a sus pies. Primero los ángeles, luego los hombres, con Adán en medio, dormido y saliendo de su costado Eva. A sus lados las naciones, con un elemento lleno de connotación: la figura de un fraile franciscano con sus indios americanos, quienes se integran en esta alegoría de pueblos a los turcos, chinos y tibetanos. En seguida la creación de las aves, entre las que un lector de fines del siglo xvı vería representadas las desconocidas de América, como el quetzal y el guajolote; luego los peces, con sus imprescindibles monstruos; y los cuadrúpe-

nández H errero, "D el bárbaro degenerado al buen salvaje (Estudios acerca del concepto del indio americano)", en Cuadernos H ispanoamericanos, núm. 536, M adrid, febrero de 1995 , pp. 7-I8.

36. Cfr. Lino Gómez Canedo, La educación de los marginados durante la época colonial, M é xico, Porrúa, I982; J osé M aría K obayaski, La educación como conquista (empresa franciscana en M éxico), M éxico, El Colegio de M éxico, I985.

37. Cfr. Arthur O. Lovejoy, The Great Chain of Being. A Study of the H istory of an Idea, Cambridge, $\mathrm{H}$ arvard U niversity Press, 1936. 


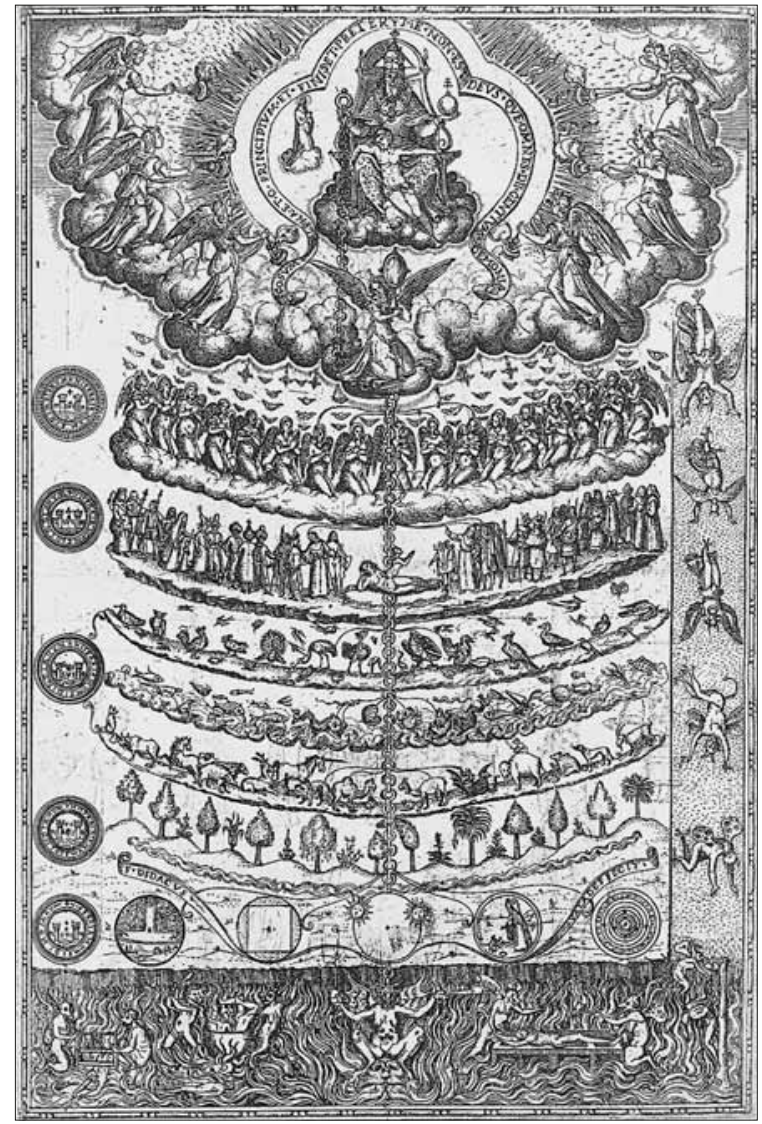

Figura 3. Alegoría esquemática de la C reación, en fray D iego Valadés, Rhetorica christiana, Perugia, I579.

dos, entre los que se identifican el mitológico unicornio y una novedad: la llama del Perú. Por último, los vegetales, con ejemplos casi todos americanos, como el nopal, el maíz, el cacao, la piña y el plátano.

En definitiva, una lectura del mundo americano integrado a la historia cristiana universal, que vendría a legitimar la condición de este nuevo componente espiritual desde una particular perspectiva retórica y teológica de la historia. La figura de un fraile franciscano con sus indios novohispanos - quienes se integran en una alegoría de pueblos paganos- plantea las bases de una particular percepción de la conquista evangelizadora como una misión 
DOI: http://dx.doi.org/10.22201/iie.18703062e.2000.77.1939

52

ROLANDO CARRASCO M.

que legitima la instauración de un nuevo orden teocrático colonial. A este respecto, $M$ ario Sartor ha precisado la función de este componente intercultural en el presente grabado:

Se è importante la presenza dell'umanità americana per la rivendicazione di una dignità assoluta nel consesso delle nazioni, e ovvia dopo la bolla Sublimis D eus di Paolo III, del I537, che la sanciva, riesce stupefacente l'annotazione attenta anche tra le schiere degli esseri inferiori di quelle specie che appartenevano al N uovo $M$ ondo, sulle quali avevano scritto già $O$ viedo e Las Casas, oltre a M artín de la Cruz e, più tardi, a partire dal 5570 , anche Francisco H ernández e, più o meno nelle stesse date, anche Sahagún..$^{8}$

La presencia del elemento americano, además de reforzar teóricamente el planteamiento de unidad de la natural eza humana, representa una de las estrategias discursivas relevantes de la obra, en la medida en que - siguiendo los postulados teológicos de Paulo III - legitima desde este contexto de re presentación la racionalidad del indígena americano, condición que le garantiza el acceso a la fe cristiana. Sin embargo, considero que existe otra dimensión no explicada por la crítica, cuya relevancia en la definición del status del indio americano ha sido olvidada. Junto a su racionalidad, la teoría canónica definió su condición de sujetos libres, principio que contradecía abiertamente las prácticas esclavistas de los españoles.39

38. M ario Sartor, Ars dicendi et excudendi: D iego Valadés incisore messicano in I talia, Padua, CLEUP, 1992, p. 39.

39. La polémica franciscana en torno al trabajo indígena en la segunda mitad del siglo XVI permite advertir los efectos de la bula del papa Paulo III de i537. El hecho de que se considerase que los naturales eran libres como los españoles y, por lo tanto, no debían ser forzados a trabajar, establece las bases teológicas de una de las oposiciones más fuertes al sistema de repartimiento forzoso de mano de obra indígena en América. A este respecto, en I584, el franciscano fray Gaspar de Recarte escribió su "T ratado del servicio personal y repartimento de los indios de N ueva España", en que confirma los alcances de esta postura: "pues los indios son libres y no esclavos, como está determinado por un breve de Paulo III anno Domini I537, y no hay cosa tan contraria a la libertad como la servidumbre, ni a la espontánea y libre voluntad como la violencia, coacción y fuerza; desto se sigue que los indios, pues son libres como los españoles, no pueden ni deben ser forzados a las sementeras de los españoles, ni a los edificios de las casas, iglesias y monasterios, y mucho menos a que sirvan por semana a los españoles en sus casas, pues el compeler a los indios a cual quiera de los dichos servicios es directo contra su libertad y es género de servidumbre..." En M ariano Cuevas, D ocumentos iné- 
DOI: http://dx.doi.org/10.22201/iie.18703062e.2000.77.1939

La probable reivindicación de estas bases teológicas y la implícita condena de quienes, por intereses materiales, negaban la condición racional y libertad del indiano nos permiten comprender que los alcances políticos de esta representación simbólica en la Rhetorica christiana no pueden disociarse de las contiendas doctrinales y políticas del siglo xvı. Este fenómeno, ya sea al interior del orden colonial como en su vinculación con la metrópolis, se traduce en una doble tensión retórico-argumentativa en torno a las prerrogativas regulares y la política vicarial.

En primer lugar, la defensa jurídico-teológica del indígena y su pertenencia al género humano es asimismo un intento de reivindicación de las prerrogativas regulares en relación con la evangelización y, específicamente, con la administración del bautismo. $4^{40}$ Interesa subrayar de qué modo esta práctica nacida original mente de la aplicación de los privilegios de los primeros regulares - entre los que encontramos al referido fray M artín de Valencia y los doce "apóstoles" - se expresa en el pensamiento valadesiano como una merma y consiguiente protesta en favor de las prerrogativas de los mendicantes frente al centralismo administrativo del clero secular:

No creo que estén libres de culpa quienes afirman que después de que han sido ya designados obispos para esas partes, tanto los religiosos como los otros ministros de D ios son ya superfluos y lo serán en el futuro. Pues en realidad de verdad los reverendísmos obispos por sí solos no podrían satisfacer a sus diócesis; y no es tiempo aún de que los indios se vean privados de los religiosos, que son los que sobrellevan todo el peso del trabajo, pondus diei et aestus. $Y$ esto no lo digo animado por un espíritu parcial, sino con toda certidumbre de que (exceptuando el que nosotros hayamos sido los primeros) los religiosos de ambas Ó rdenes de Santo D omingo y San Agustín producen grandes frutos según sus fuerzas, pues han florecido entre ellos muchos varones conspicuos por la probidad y santidad de su vida y costumbres. (483)

ditos del siglo xvı para la historia de M éxico, M éxico, M useo $\mathrm{N}$ acional de Arqueología, $\mathrm{H}$ istoria y Etnología, 1914, pp. 354-385.

40. La contienda doctrinal que surgió durante el primer tercio del siglo xvı en contra de los métodos bautismales de los franciscanos forma parte de un episodio en el que incluso el dominico fray Bartolomé de las Casas atacaría duramente el bautismo colectivo y la escasa instrucción de los indianos por parte de los minoritas. Cfr. Claudio Cecchrelli, "EI bautismo y los franciscanos en M éxico (I524-I539)", en M issionalia H ispanica, año XII, núm. 35, M adrid, I955, pp. 209-289. 
DOI: http://dx.doi.org/10.22201/iie.18703062e.2000.77.1939

54

ROLANDO CARRASCO M.

En segundo lugar, la defensa de este sistema de apostolado se traduce en un intento de legitimación de la evangelización franciscana frente a la autoridad imperial. Se trataría de la proposición de un modelo teocrático de sociedad, según observaremos más adelante, que puede ser entendido como una réplica de autonomía de la iglesia indiana ante las ambiciones y aspiraciones vicariales de Felipe II, quien en 1577 habría de ser determinante en la salida de Valadés de su cargo de Procurador G eneral de la orden en Roma. ${ }^{4}$

Aquí reside, a nuestro entender, el principio explicativo de un cambio importante en la función retórico-argumentativa de la Rhetorica christiana, en la medida en que sus "ejemplos de indios", supuestos reflejos de la práctica de la oratoria sagrada en N ueva España, son también la base argumentativa de una disputa o controversia judicial en defensa del utopismo evangelizador de los regulares frente a las presiones vicariales. Ya la retórica clásica había advertido que la controversia era una "cuestión debatida" o "pleito" por ambas partes en disputa y, por ende, más representativa del carácter dialéctico del género judicial (acusación-defensa), ${ }^{42}$ lo que nos permite considerar el alcance persuasivo de la utilización demostrativa (elogio-vituperio) de los ejemplos valadesianos, en la medida en que polemizan la visión peninsular sobre el indígena novohispano y reivindican la acción minorita en el $\mathrm{N}$ uevo

4I. C abe señalar que el registro valadesiano se inscribe en un contexto de circulación textual que contravenía abiertamente la prohibición que en 1575 hiciera Felipe II de dar noticias sobre la evangelización del $\mathrm{N}$ uevo $\mathrm{M}$ undo. A este respecto puede consultarse el trabajo de Juan Friede, "La censura española del siglo xvı y los libros de historia de América", en Revista de H istoria de América, núm. 47, M éxico, 1959, pp. 45-94. Por otro lado, según ha documentado I saac Vázquez Janeiro, se trataría de una obra publicada sólo dos años después de la salida de V aladés de su cargo como Procurador General de la orden franciscana en Roma. U na supuesta transgresión a la política del regio vicariato indiano justificaría las presiones del monarca ante la Santa Sede y la salida del fraile franciscano de la administración espiritual de las Indias. Op. cit., pp. 858-863.

42. Cfr. H einrich Lausberg, M anual de retórica literaria, M adrid, Gredos, 1975, p. I57. D ebemos considerar que tanto para Valadés como para el retórico español fray Luis de G ranada, el género judicial es propio de procuradores y litigantes, abarca la acusación y defensa o la demanda judicial y su contestación, por ende, no pertenecía a los predicadores de la palabra divina, lo que explica su exclusión de sus respectivos tratados. C fr. op. cit., p. 453. En esta perspectiva, compárese con la obra de V aladés, $D$ efensa del sincero cristianismo de los indios frente a las acusaciones de pagani smo indígena, cap. XI, pp. 425 SS.: "Se trata de la inconsiderada acusación que hacen algunos contra los indios, diciendo que éstos no vienen a ser más cristianos que lo son los moros de G ranada". 
DOI: http://dx.doi.org/10.22201/iie.18703062e.2000.77.1939

M undo. Acusaciones como que los indígenas todavía observaban con fidelidad sus antiguas costumbres y ceremonias, que eran incapaces de comprender la fe cristiana, además de que su amor sería servil pues estaban movidos por el temor, y que, en síntesis, eran proclives a la herejía y a la rebelión, motivaron su esfuerzo de réplica:

A éstas pueden reducirse las acusaciones alegadas por algunos; las cuales refirió en mi presencia y en el palacio de una dama principal, y conocida de la corte del rey católico, cierto noble que había estado por varios años en las mismas Indias. Por lo cual me sentí movido a traer a cuento lo verdadero y lo dudoso sobre lo que se refiere a los indios; y esto ha sido examinado y visto por mí mismo, pues he morado entre ellos (loado sea D ios) treinta años más o menos, y me dediqué durante más de veintidós años a predicarles y confesarlos en sus tres idiomas: mexicano, tarasco, otomí, y no me dejo llevar imprudentemente por afecto alguno, sino que me guía únicamente el deseo de que se conozca la verdad. (425)

En definitiva, el principio de veracidad experiencial que introduce Valadés en su controversia sobre la efectividad de la labor misionera en N ueva España corresponde a un recurso que no sólo connota el carácter de su discurso historiográfico (narración de hechos verdaderos), sino que además representa una estratagema persuasiva que mediante la controversia busca refutar aquello de que han sido vituperados los indígenas. 43 Tal actitud se sintetiza en palabras del fraile mestizo en una conceptualización del género demostrativo que se presenta en estrecha relación con la historia, pues: "este género demostrativo es considerado como la síntesis de todo, porque por él se manifiesta lo que hay en una persona digno de alabado o vituperado; por lo tanto, corresponde este género principalmente a los historiadores". 44 En definitiva, Valadés, sirviéndose de las modalidades preceptivas del género demostrativo, pretende elaborar con estos ejemplos novohispanos una "verdadera" historia de las Indias. El aspecto redunda, en primer lugar, en una

43. Valadés, op. cit., p. 425 .

44. Ibidem, p. 459. Es importante considerar que para la retórica sagrada los componentes del género epidíctico eran especialmente relevantes para el sermón hagiográfico, tal como se puede confirmar en el libro IV de la Retórica de fray Luis de Granada. La concepción valadesiana, dentro de los moldes de la teoría preceptiva tradicional, en ningún caso pretende "colocar a los indios entre los santos", sino refutar las opiniones vituperables. 
DOI: http://dx.doi.org/10.22201/iie.18703062e.2000.77.1939

56 ROLANDO CARRASCO M.

transformación de las prácticas discursivas en relación con el sermón epidíctico (cuya base eran las vidas de santos); y, en segundo lugar, en una actualización de la indisoluble relación entre retórica y ética, tan cara a los humanistas del Renacimiento.45

Un modelo teocrático de sociedad novohispana

Un aspecto final que debemos considerar en relación con la perspectiva valadesiana sobre la acción evangelizadora en el $\mathrm{N}$ uevo $\mathrm{M}$ undo es, a mi modo de entender, la misión providencialista que rodea la imagen de fray M artín de Valencia y sus acompañantes en el surgimiento de la I glesia indiana. ${ }^{46} \mathrm{En}$ tal sentido, una de las claves ideológicas que diferenciaron el primitivo franciscanismo novohispano durante la primera mitad del siglo Xvı es aquella que aúna el interés misional por la predicación con la inminencia del fin del mundo. La emergente cristiandad americana se constituye en un modelo alternativo de sociedad que - desde una específica forma de percepción de la historia- concibe la conquista como una misión mística.

En esta "nueva I glesia", contrapuesta a la decadente espiritualidad europea, resuenan los ecos del Kairós o experiencia del fin de la H istoria, principio que no sólo sería parte de las creencias de fray M artín de Valencia, sino también de fray Toribio de Benavente o M otolinía y fray Jerónimo de $\mathrm{M}$ endieta. ${ }^{47}$ Como bien sabemos, la consideración finita del tiempo tendría en la empresa misional franciscana en M éxico su origen en la cultura bajomedieval, gracias a la influencia del pensamiento de Joaquín de Fiore. Su obra inauguró una verdadera profetología de las edades del mundo con incidencia en la vida política, social y cultural del mundo occidental. Los anhelos de re-

45. Cfr. Karl Kohut, "Retórica, poesía e historiografía en Juan Luis Vives, Sebastián Fox M orcillo y Antonio Llull", en Revista de Literatura, t. LII, núm. Io4, M adrid, julio-diciembre de i99o, pp. 364-374.

46. En relación con este primer periodo de la evangelización en M éxico, que se inicia en I524 con la llegada de fray M artín de Valencia y los doce "apóstoles", véase el trabajo de Robert Ricard, La conquista espiritual de M éxico. Ensayo sobre el apostolado y los métodos misioneros de las órdenes mendicantes de la N ueva España de I523-24 a I572, M éxico, Fondo de Cultura Económica, 1986.

47. Cfr. José Sala Catalá y Jaime Vilchis Reyes, "Apocalíptica española y empresa misional en los primeros franciscanos de M éxico", en Revista de Indias, vol. XLV, núm. I76, M adrid, I985, pp. 444-456. 
DOI: http://dx.doi.org/10.22201/iie.18703062e.2000.77.1939

forma y la nostalgia desesperada por la utopía de la iglesia primitiva de C risto cristalizan en el pensamiento utópico del abad calabrés en un proceso de profundo cambio, pues a la destrucción simbólica de la iglesia romana sobrevendría el nacimiento de la iglesia nueva del milenio..$^{8}$

La creación de un modelo teocrático de sociedad con una proyección utópica es una aspiración que podemos corroborar también en la Rhetorica christiana. La representación alegórica de los doce frailes de Nueva España (figura 4), quienes llevan sobre sus hombros a la nueva espiritualidad en América, se completa con las figuras de san Francisco y fray M artín de Valencia. M ientras a los lados se desarrollan escenas de la evangelización indiana (la enseñanza de la C reación, el matrimonio, el bautismo, la confesión, etc.). En síntesis, toda una simbiosis del catolicismo en ciernes y sus respectivas prácticas pastorales en Indias, bajo una inscripción no menos significativa: "Representación de las actividades que realizan los $\mathrm{H}$ ermanos menores en el $\mathrm{N}$ uevo $\mathrm{M}$ undo de las indias conforme a lo que estaba escrito. Te extenderás hacia el 0 riente y el 0 ccidente, hacia el M ediodía y el Septentrión y Yo seré quien cuide de ti y de tus empresas."

Según Patricia N ettel, el referente de esta parte de la descripción de Valadés, contenida en este grabado de la Fundación de la I glesia mexicana y de la evangelización, es la profecía de Joaquín de Fiore, para quien en el futuro se realizaría el predominio de una comunidad monástica de santos que regeneraría al mundo por medio del Evangelio. La realización de esta profecía al parecer se cumpliría en América. D e esta forma, la seguridad de poder alcanzar los lejanos países del 0 riente, navegando siempre hacia 0 ccidente, y de que el cristianismo completara su travesía, pareció ser una de las señales de que el esperado final de los tiempos estaba cercano.49 Tal elemento confirmaría en la Rhetorica christiana la persistencia de un proyecto evangelizador que - si bien para Valadés es materia de una crónica histórica- se plantea como una visión optimista de los primeros momentos de la utopía cristiano-social no-

48. John Leddy Phelan, El reino milenario de los franciscanos en el N uevo M undo, M éxico, Universidad N acional Autónoma de M éxico, 1972.

49. Cfr. Patricia N ettel D., "Cosmovisión y cultura material franciscana en los pueblos de indios de N ueva España según fray D iego Valadés (una perspectiva etnográfica)", en Elsa Ce cilia Frost (coordinadora), Franciscanos y mundo religioso en M éxico, M éxico, U niversidad $\mathrm{N}$ acional Autónoma de M éxico, 1993, pp. 39-53. 
DOI: http://dx.doi.org/10.22201/iie.18703062e.2000.77.1939

58

ROLANDO CARRASCO M.

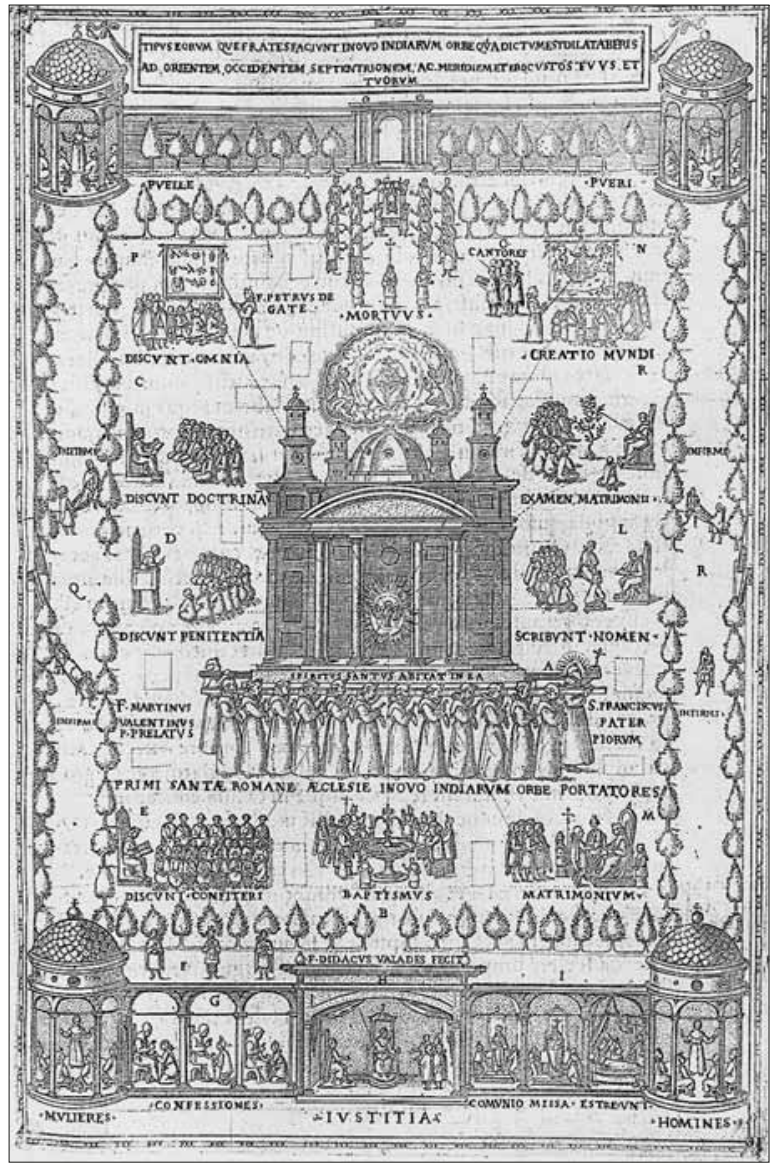

Figura 4. Alegoría de la I glesia mexicana y de la evangelización, en fray D iego V aladés, Rhetorica christiana, Perugia, 1579.

vohispana, lo que pretende fortalecer su estrategia argumentativa sobre la efectividad de los métodos pastorales ya en el origen de la iglesia indiana.

Conjuntamente con esta interpretación de la historia, la legitimación de los proyectos evangelizadores franciscanos en $N$ ueva España también requirió de un método pastoral que Valadés describe en su Rhetorica con ciertos episodios cotidianos de la catequesis, por medio de varios grupos (identificados con letras del alfabeto) dispuestos de manera diferente en un gran atrio 
DOI: http://dx.doi.org/10.22201/iie.18703062e.2000.77.1939

con cuatro capillas posas en sus ángulos.50 La legitimación de la condición racional del indígena, como ya hemos demostrado, lo convierte en un sujeto capaz de ser incorporado a una historia cristiana universal, gracias a la conversión. Sirva como ejemplo de esta metodología pastoral su descripción del bautismo y la confesión:

B. Aquí es de verse con cuánta reverencia celebran y administran el muy santo sacramento del Bautismo y los otros divinos sacramentos. Pues avanza primero el religioso, revestido muy cuidadosamente con los ornamentos, lo cual se observa aun en el bautismo de uno solo [... ] Estas ceremonias se omiten, sin embargo, cuando la necesidad pide que se proceda con rapidez. Pues, en caso de inminente peligro de muerte, se administra el bautismo con pura agua, que siempre tiene a mano para este uso; pues por la tarde, antes de irse a comer, ponen a la entrada del monasterio un vaso lleno de agua para tenerlo a la mano tan pronto como toquen la campanilla. El dicho toque es señal segura de que acaban de llevar a alguna persona que está en grave peligro de muerte para que reciba el bautismo. (473)

E. Acostumbran entre ellos, después de haber escuchado la instrucción catequística de la que ya se hizo mención, recitar todos a una, con grande atención, la confesión general. Una vez terminada ésta, se les lee el modo de confesarse siguiendo por orden los D iez M andamientos, lo que escuchan con suma atención, y mientras están oyendo anotan por medio de granos de maíz o piedritas los pecados y su número, con sus circunstancias; 0 dibujan figuras o imágenes, y de este modo se confiesan bien, con claridad y facilidad. (483)

Cabe señalar que la elocuencia cristiana, principio decisivo en la introducción de esta práctica doctrinal, se transforma claramente en una importante estrategia de aculturación y organización del espacio indiano. Ya el mismo Valadés lo había señalado: "después de que han sido reunidos [los indígenas] en pueblos y ciudades, para vivir en sociedad, viven hasta tal grado política y cristianamente". ${ }^{\text {II }}$ En su descripción epidíctica de esta fundación de la iglesia indiana, el templo-monasterio ocupa el centro urbano, especialmente me-

50. Cfr. John M c Andrew, The 0 pen-Air Churches of Sixteenth-Century M exico, C ambridge, $\mathrm{H}$ arvard U niversity Press, 1965, pp. 293-295.

5r. Valadés, op. cit., p. 437. 
DOI: http://dx.doi.org/10.22201/iie.18703062e.2000.77.1939

60

ROLANDO CARRASCO M.

diante la caracterización del atrio como lugar de adoctrinamiento. En tal sentido, la morfología de este nuevo orden simbólico se plantea como el ideal organizativo de un proyecto de estado indo-cristiano que, probablemente signado por las concepciones joaquinistas de los primeros frailes, representa un ejemplo significativo sobre la nueva condición política y espiritual de los integrantes de esta república cristiana.52

Un elemento no menos importante en este grabado es la reiteración de la figura de fray M artín de Valencia y los primeros "apóstoles" americanos, quienes llevan en hombros, al egóricamente, a la nueva iglesia indiana, acompañados por san Francisco, "Patriarca de los pobres, quien es como la raíz y portaestandarte en esta propagación de la fe cristiana." En su conjunto, símbolos inscritos en el centro de una práctica litúrgica, que en Valadés representan la esperanza de una renovación de la I glesia romana. Propuesta alternativa que, según ha advertido la crítica, se apoya en las virtudes de un tiempo pasado que debe restaurarse ante la inminencia del momento justo de la Gracia, la plenitud del tiempo (Kairós). 53 En tal sentido, advertimos el eco tardío de un providencialismo aún operante en el ideario apostólico de fray $D$ iego Valadés quien, distante ya varias décadas de los primeros momentos de la evangelización, pretende darnos a conocer una visión gloriosa de los inicios de la evangelización novohispana. La perspectiva no es menos importante al momento de considerar el alcance de su argumentación retórica en defensa de la debatida condición espiritual del indiano y la efectividad de la práctica apostólica de los minoritas, en momentos en que la conquista de las "Indias de la Tierra" dejaba sentir sus irreversibles efectos secularizantes sobre las "Indias del Cielo".

52. C fr. Leopoldo A. García Lastra, "Joaquinismo, profecía y apocalipticismo. La utopía Angelopolitana, Jerusalén celeste de la N ueva España", en V Congresso Internazionale di Studi Gioachimiti, S. Giovanni in Fiore (CS), Centro Internazionale di Studi Gioachimiti, 20oI, pp. I05-I38.

53. Alain M ilhou, "El concepto de 'destrucción' en el evangelismo milenario de los franciscanos", en Actas del II C ongreso Internacional sobre los Franciscanos en el N uevo M undo (siglo XVI), M adrid, D eimos, I987, pp. 297-316. 
DOI: http://dx.doi.org/10.22201/iie.18703062e.2000.77.1939

EL EXEMPLUM COMO ESTRATEGIA PERSUASIVA

\section{Conclusión}

Uno de los primeros aspectos que cabría puntualizar en este ensayo es la necesidad de profundizar en la complejidad discursiva de la Rhetorica christiana desde una relectura de sus estrategias argumentativas, que surgen de la interacción del nivel preceptivo e iconográfico. En esta perspectiva, la función retórica de los exempla nos permite reconocer que tras su valor de icono verbal con carácter probatorio, la obra de fray D iego Valadés no sólo presenta una importante significación literaria, sino también de orden teológico y jurídico.

La estrategia narrativa de índole experiencial que sirve de base para esta crónica novohispana representa un instrumento de legitimación que mediante la utilización del género demostrativo no sólo persigue dar a conocer una visión de los primeros tiempos del proceso de aculturación espiritual, sino también desplegar las bases de una controversia, tendiente a rebatir las acusaciones contra el falso cristianismo indiano y, por ende, aquellas sobre la efectividad de la acción misionera en la conquista espiritual del Nuevo M undo. Para tal es efectos, la experiencia misionera de Valadés, además de advertirnos sobre el valor de la elocuencia en la fundación de la comunidad indo-cristiana, se nutre de un conjunto de concepciones que, en el campo de las ideas del siglo XVI, exigen ser reconsideradas para una mejor comprensión de las bases argumentativas de la Rhetorica christiana. D esde esta perspectiva, la incorporación del mundo americano en una unidad de la naturaleza humana se asienta en la interpretación del idolatrismo prehispánico como acción del demonio. Los alcances de esta tradición teológica, ya presente en M otolinía, no sólo marcan la transformación de la "barbarie" y el "paganismo" indiano hacia una nueva identidad espiritual, sino también sirven de justificación a la misión apostólica.

D esde su representación y comentario al grabado alusivo al Templo y costumbres indígenas hasta la gran cadena del Ser en su Alegoría de la Creación, el registro del mundo americano se inscribe en este tránsito de integración en una historia cristiana universal, proceso que implícitamente conlleva una reafirmación de la condición racional y libertad del indígena, sancionadas por Paulo III en 1527. Este aspecto asimismo se inscribe en el marco de una probable reivindicación de las prerrogativas regulares en relación con los métodos bautismales, como también en una legitimación de la evangelización franciscana frente a la autoridad imperial que, en última instancia, era un 
62 ROLANDO CARRASCO M.

protagonista directo en la polémica sobre el sistema de repartimiento forzoso de mano de obra.

Dichos aspectos nos llevan a considerar que en este elogio de la acción apostólica en N ueva España los ejemplos de conversión representan la base de una controversia en torno a la condición del indiano y defensa del orden teocrático colonial. De esta forma, el utopismo evangelizador valadesiano, más allá de su probable filiación joaquinista, es una representación optimista de los primeros tiempos de la conquista espiritual novohispana que, además de señal ar las bases pastoral es para la conversión del indígena, constituye una de las últimas respuestas del siglo XVI ante las presiones del centralismo virreinal.\$ 
DOI: http://dx.doi.org/10.22201/iie.18703062e.2000.77.1939

EL EXEMPLUM COMO ESTRATEGIA PERSUASIVA

\section{Bibliografía}

Fuentes

Focher, Juan, Itinerario católico del misionero en América, texto latino con versión castellana, introducción y notas de Antonio Eguiluz, M adrid, Librería General Victoriano Suárez, 1960.

Valadés, fray Diego, Retórica cristiana, introducción de Esteban J. Palomera, traducción de Tarsicio Herrera Zapién et al., M éxico, U niversidad N acional Autónoma de M éxico, Fondo de Cultura E conómica, 1989.

, Indianischer Religi onstandt der gantzen neuen Welt, beider Indien gegen auff (und) nidergang der Sonnen, Ingolstadt, I588 (microficha).

Bibliografía crítica

Abbott, D on Paul, "D iego Valadés. An Ancient Art in a N ew W orld", en Rhetoric in the N ew W orld. Rhetorical Theory and Practice in Colonial Spanish America, Columbia, South Carolina Press, 1996, pp. 4I-59.

Alejos-G rau, Carmen J osé, D i ego Valadés, educador de la N ueva España. I deas pedagógi cas de la Rhetorica christiana (Is79), Pamplona, Eunate, r994.

Briesemeister, D ietrich, "La estela de N ebrija en el N uevo M undo: la gramática y retóricas latinas", en Karl Kohut y Sonia Rose (editores), Pensamiento europeo y cultura colonial, Frankfurt del M ain, Vervuert-M adrid, Iberoamericana, 1997, pp. 52-67.

García L astra, Leopoldo A., "J oaquinismo, profecía y apocalipticismo. La utopía angelopolitana, Jerusalén celeste de la N ueva España", en V Congresso Internazionale di Studi Gioachimiti, S. Giovanni in Fiore (cs), Centro Internazionale di Studi Gioachimiti, 20oI, pp. 354-37I.

Gerlero, Elena Isabel, de "La demonología en la obra gráfica de fray D iego Valadés", en I conología y sociedad. Arte colonial hispanoamericano, XLIV Congreso Internacional de Americanistas, M éxico, U niversidad N acional Autónoma de M éxico, Instituto de Investigaciones Estéticas, 1987, pp. 79-89.

M aza, Francisco, de la "Fray D iego Valadés. Escritor y grabador franciscano del siglo Xvı", en A nales del Instituto de Investigaciones Estéticas, núm. I3, M éxico, 1945, pp. 97-159.

M éndez Plancarte, G abriel, H umanismo mexicano del siglo Xvı, M éxico, U niversidad N acional Autónoma de M éxico, 1946.

M ignolo, W alter, "Palabras pronunciadas con el corazón caliente: teorías del habla, del discurso y de la escritura", en Ana Pizarro (coordinadora), América Latina. Palavra, literatura e cultura. Formações discursivas coloniais. Vol. I. A situacão colonial, São Paulo, Fundacão M emorial da América Latina Campinas, U IICAM P, I993, pp. 527-562.

, "El metatexto historiográfico y la historiografía indiana", en M odern Language N otes, vol. 96, núm. 2, Baltimore, 1981, pp. 358-402.

N ettel, Patricia, "Cosmovisión y cultura material franciscana en los pueblos de indios de 
DOI: http://dx.doi.org/10.22201/iie.18703062e.2000.77.1939

\section{4}

ROLANDO CARRASCO M.

N ueva España según fray Diego Valadés (una perspectiva etnográfica)", en Elsa Cecilia Frost (coordinadora), Franciscanos y mundo religioso en M éxico, M éxico, U niversidad $\mathrm{Na}$ cional Autónoma de M éxico, 1993, pp. 39-53.

O sorio Romero, I gnacio, Floresta de gramática, poética y retórica en N ueva España (I52I-I767), M éxico, U niversidad N acional Autónoma de M éxico, 1980.

Palomera, Esteban J., Fray D iego Valadés O. F. M . Evangelizador humanista de la N ueva España, M éxico, Jus, 1962.

Reyes Coria, Bulmaro et al., Acerca de fray D iego Valadés. Su Retórica cristiana, M éxico, U niversidad $\mathrm{N}$ acional Autónoma de M éxico, 1996.

Sartor, M ario, Ars dicendi et excudendi, D iego Valadés incisore messicano in Italia, Padua, CLEUP, I992.

Sebastián, Santiago, "EI franciscano Valadés y la capilla abierta", en I conografía del arte del sglo xvı en M éxico, M éxico, U niversidad Autónoma de Zacatecas, I995, pp. IOI-IO4.

Taylor, René C., El arte dela memoria en el N uevo M undo, M adrid, Swan, 1987.

Vázquez Janeiro, I saac, "Fray Diego Valadés. N ueva aproximación a su biografía", en Actas de II Congreso Internacional sobre los Franciscanos en el N uevo M undo (siglo XvI), M adrid, Deimos, 1987, pp. 843-87I.

Estudios generales

Aínsa, Fernando, "La utopía empírica del cristianismo-social" (I513-1577), en Ana Pizarro (coordinadora), América Latina. Palavra, literatura e cultura. Formações discursivas coloniais. V ol. I. A situacão colonial, São Paulo, Fundacão M emorial da América Latina Campinas, UNICAMP, 1993, pp. 87-IO9.

Aristóteles, Retórica (traducción, prólogo y notas de Antonio T ovar), M adrid, Instituto de Estudios Políticos, I953.

Borges, Pedro, "La Santa Sede y América en el siglo xvı", en Estudios Americanos. Revista de Síntesis e Interpretación, vol. xxı, núm. I07, Sevilla, marzo-abril de i96I, pp. I4I-I68.

Ceballos, Francisco Javier, "I mitatio, aemulatio, elocutio. H acia una tipología de las poéticas de la época colonial", en Revista I beroamericana, LXI, I72-I73, Pittsburg, julio-diciembre de I995, pp. 50I-5I5.

Cecchrelli, Claudio, "El bautismo y los franciscanos en M éxico (I524-I539)", en M issionalia H ispanica, año XII, núm. 35, M adrid, 1955, pp. 209-289.

Cicerón, M arco Tulio, D e la invención, traducción de N icolás Estévanez, París, Garnier H nos., s. f., t. I.

Cuevas, Cristóbal, "Para la historia del exemplum en el barroco español (El itinerario de Andrade)", en Edad de O ro, núm. 8, M adrid, i989.

Cuevas, M ariano, D ocumentos inéditos de siglo Xvı para la historia de M éxico, M éxico, M useo $\mathrm{N}$ acional de Arqueología, $\mathrm{H}$ istoria y Etnología, i9ı4.

Fernández H errero, Beatriz, "D el bárbaro degenerado al buen salvaje (estudios acerca del concepto del indio americano), en Cuadernos $\mathrm{H}$ ispanoamericanos, núm. 536, M adrid, febrero de 1995 , pp. 7-18. 
DOI: http://dx.doi.org/10.22201/iie.18703062e.2000.77.1939

EL EXEMPLUM COMO ESTRATEGIA PERSUASIVA

Friede, J uan, "La censura española del siglo xvı y los libros de historia de América", en Revista de Historia deAmérica, núm. 47, M éxico, 1959, pp. 45-94.

Frost, Elsa Cecilia, "La visión providencialista de la historia", en Filosofía iberoamericana en la época de Encuentro, M adrid, Trotta, I992, pp. 33I-345.

Gómez Alonso, Juan Carlos, "Retórica y poética en los siglos XVI y XVII: la operación retórica de memoria", en Edad de0 ro, núm. 19, M adrid, 2000, pp. I2I-I30.

Gómez Canedo, Lino, La educación de los marginados durante la época colonial, M éxico, Porrúa, 1982.

Guzmán Betancourt, I gnacio, "La lengua, ¿compañera del imperio? D estino de un 'presagio' nebrisense en la N ueva España", en Cuadernos Americanos, año VII, vol. I, núm. 37, M éxico, enero-febrero de i993, pp. I48-I64.

H errero Salgado, Félix, La oratoria sagrada española de los siglos XVI y XVII, M adrid, Fundación Universitaria Española, 1996.

Kobayaski, José M aría, La educación como conquista (empresa franciscana en M éxico), M éxico, El Colegio de M éxico, 1985.

Kohut, Karl, Las teorías literarias en España y Portugal durante los siglos XVI y XVII, M adrid, Consejo Superior de Investigaciones Científicas, 1973.

"Retórica, poesía e historiografía en Juan Luis Vives, Sebastián Fox M orcillo y Antonio Llull", en Revista de Literatura, t. LII, núm. I04, M adrid, julio-diciembre de ı990, pp. 364-374.

Lausberg, $\mathrm{H}$ einrich, M anual de retórica literaria, M adrid, G redoS, I975.

López Grigera, Luisa, "Corrientes y generaciones en la retórica del siglo XVı en España”, en La retórica en la España del Siglo de Oro. Teoría y práctica, Salamanca, U niversidad de Salamanca, I994.

Lovejoy, Arthur $\mathrm{O}$., The Great Chain of Being. A Study of the H istory of an I dea, Cambridge, $\mathrm{H}$ arvard U niversity Press, 1936.

M artí, Antonio, "La retórica sacra en el Siglo de O ro", en H ispanic Review, vol. xxxVIII, núm. 3, Filadelfia, julio de 1970, pp. 264-298.

La perceptiva retórica española en el Siglo de 0 ro, M adrid, G redos, I972.

$M$ athes, M iguel, Santa Cruz de T latelol co: la primera biblioteca académica de las Américas, M éxico, Secretaría de Relaciones Exteriores, 1982.

M c Andrew, John, The 0 pen-Air Churches of Sixteenth-C entury M exico, Cambridge, $\mathrm{H}$ arvard U niversity Press, 1965.

Milhou, Alain, "El concepto de 'destrucción' en el evangelismo milenario franciscano", en Actas del II Congreso Internacional sobre los Franciscanos en el N uevo M undo (siglo XVI), M adrid, Deimos, 1987, pp. 297-316.

M urphy, James J., Sinopsishistórica de la retórica clásica, M adrid, G redos, 1989.

N ieto, M aría D olores, Estructura y función de los relatos medievales, M adrid, Biblioteca de Filología H ispánica, C onsejo Superior de Investigaciones Científicas, 1993.

O sorio Romero, I gnacio, "La retórica en N ueva España", en Dispositio. Revista H ispánica de Semiótica Literaria, vol. VIII, núms. 22-23, M ichigan, 1983, pp. 65-86. 
DOI: http://dx.doi.org/10.22201/iie.18703062e.2000.77.1939

66 ROLANDO CARRASCO M.

Phelan, John Leddy, El reino milenario de los franciscanos en el N uevo M undo, M éxico, U niversidad N acional Autónoma de M éxico, 1972.

Q uintiliano, M arco Fabio, Instituciones oratorias, M adrid, Librería de la Viuda de $\mathrm{H}$ ernando y Cía., I887, 2 vols.

Ricard, Robert, La conquista espiritual de M éxico. Ensayo sobre el apostolado y los métodos misioneros de las órdenes mendicantes de la N ueva España de I523-24 a I572, M éxico, Fondo de Cultura Económica, 1986.

Rico Verdú, José, La retórica española de los siglos XVI y XVII, M adrid, Consejo Superior de Investigaciones C ientíficas, I973.

Roig, Arturo Andrés, "M omentos y corrientes del pensamiento humanista durante la época de la colonia hispanoamericana, Renacimiento, Barroco e llustración", en Revista de Filosofía, vols. XXI-XXII, Santiago, diciembre de 1993, pp. 55-83.

Sala Catalá, José y Jaime Vilchis Reyes, "Apocalíptica española y empresa misional en los primeros franciscanos de M éxico", en Revista de Indias, vol. XLV, núm. I76, M adrid, 1985, pp. $444-456$.

U rbano, H enrique, La extirpación de la idolatría en el Pirú ( $\left.{ }_{\text {I6 }} I I\right)$. Pablo J oseph de Arriagada de la Compañía de Jesús, C uzco, CBC, I999. 